\title{
Controlling the Quality of Industrial Engineering and Management Education: Structural Analysis of Austrian Degree Programs and Implications for Higher Education Institutions
}

\author{
Ulrich Bauer \\ Graz University of Technology, Head of Institute of Business Economics and Industrial Sociology, and former \\ Vice-Rector for Human Resources, Finance and Portfolio Management, Graz University of Technology, Institute \\ of Business Economics and Industrial Sociology, Kopernikusgasse 24/II, 8010 Graz, Austria, \\ ulrich.bauer@tugraz.at \\ Sigrid Weller \\ Graz University of Technology, Research and Teaching Assistant, Graz University of Technology, Institute of \\ Business Economics and Industrial Sociology, Kopernikusgasse 24/II, 8010 Graz, Austria, sigrid.weller@tugraz.at
}

Received (28.12.2018.); Revised (22.01.2019.); Accepted (13.02.2019.)

\begin{abstract}
Industrial Engineering and Management (IEM) degree programs have always been popular and successful, especially during the last thirty years. Many Higher Education Institutions (HEI) offer a wide range of study programs, and this range continues to expand. This has led to the problem that different programs and qualification profiles are no longer clearly comparable. The Austrian Association of IEMs (WING) sought a solution which woulden sure the high quality of IEM degree programs and the employability of IEM professionals. Therefore, a controlling approach was chosen, which led to satisfactory results, primarily with regard to transparency. This paper presents the approach and the results of a structural analysis and two online surveys, conducted as part of the IEM Profession Online Study carried out in 2018.
\end{abstract}

Key words: Industrial Engineering and Management, Degree Program, Controlling, Higher Education Institution, Qualification profile, Employability, Quality

\section{INTRODUCTION}

In German-speaking countries such as Germany and Austria, Industrial Engineering and Management (IEM) study programs have had a long tradition. The first IEM study program, the so-called "Wirtschaftsingenieurwesen" was established in 1927 at the Technische Hochschule Berlin-Charlottenburg (today called the Berlin University of Technology) [1], and the first Austrian IEM study program was established in 1947 at the Technische Hochschule Graz (today called the Graz University of Technology). Originally, the ratio of technological to economic subjects offered in this program was approximately 70 to $30[2]$. Today, IEM study programs are highly successful, and the employment rates of IEM professionals are high. This makes IEM educational program attractive to both universities and universities of applied sciences, both of which are considered "Higher Education Institutions" (HEIs).

Furthermore, the term "Wirtschaftsingenieurwesen" has become widely understood throughout Europe as an industrial, academic and theoretical discipline. Therefore, in Austria, Germany and Switzerland, the landscape of IEM study programs has developed rapidly since 1999 . This caused a problem in that some IEM programs only included a small number of technological subjects, and graduates from these programs received fewer technological competencies. A common complaint from Human Resource (HR) Managers, and especially from managers at "technologically-oriented companies" or "technology firms", has been that "there is no longer an engineer inside". It has become clear that some forms of regulation and guidelines are necessary. Currently, there is no specific legal frame work available to control this development beyond the 1999 Bologna Declaration, which only provides certain objectives [3] and a framework of assigned credit points (ECTS) for each HEI degree program $[4,5]$ and the ECTS workload [6]. The independent special interest group "Austrian Association of IEMs" encouraged researchers to ask the following research questions: "How can we protect the high quality of IEM education in Austria?", "How can we ensure the high employment rate of our graduates within their appropriate disciplines?", "How can we control HEls without encountering legal difficulties?" and "Is the controlling philosophy an appropriate approach?" 
This paper is structured as follows: In Section 1, we give a brief summary of the difficulties encountered while searching for a solution to this problem and the questions that were derived during this process. In Section 2, we outline a framework of the controlling approach taken and explain relevant terms and definitions. The methodical approach taken to conduct the study is described in Section 3. In Section 4, we present selected results and indicate the limitations and conclusions of this study in Section 5.

\section{THE CONTROLLING APPROACH, TERMS AND DEFINITIONS}

The first step that is normally taken is to establish a set of terms that are related to controlling, IEM, TechnoEconomics (TE) and HEl-management.

Generally, the Controller's Mission Statement is defined as "Partners of management controllers effecting a significant contribution to the successful sustainability of the organization'[7]. This means that a controller acts as a partner for a manager in the decision-making processes that occur within a company. The controller supports a manager by providing information as a "navigator" and contributes to the decision-making process. Figure 1 shows the well-known intersection model, which shows the manager and controller working as a team [8].

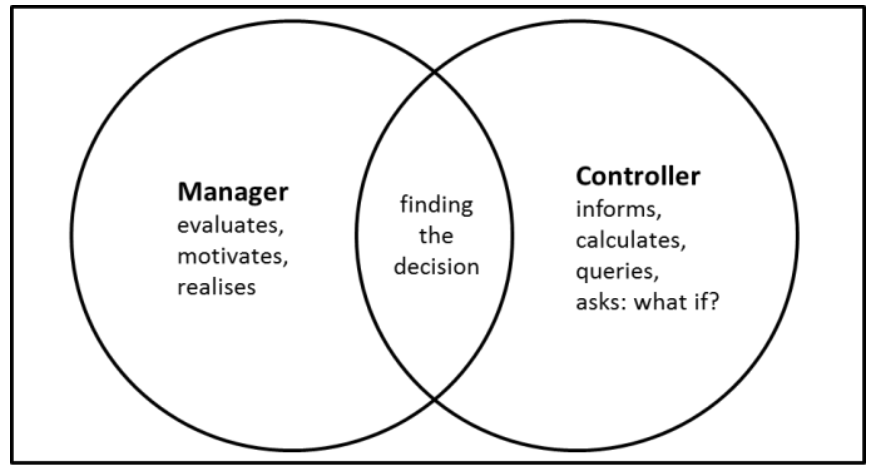

Figure 1. Intersection model showing the manager and controller acting as a team

The manager operates the business and is responsible for obtaining results. The controller is responsible for collecting information that is relevant to the decision and acts as a" sparring partner." [12]

To describe their role in more detail, controllers [7]:

1. design and assist the management process by defining goals, planning and management control, so that everyone involved in the decision-making process can act in accordance with the objectives that have been agreed upon;

2. ensure a state of preparation for the future, and thus make it possible to take advantage of opportunities while minimizing risks;

3. integrate an organization's goals and plans into a cohesive strategy; and
4. develop and maintain all management control systems to ensure the quality of data and provide information that is relevant to the decision-making process;

5. act as the "economic conscience," and thus are committed to protecting the overall welfare of the organization."

The different roles of the manager and controller must be defined within an organization. If we broaden this "classic controlling approach", we can transfer the role of a manager in a company to a study program manager of an $\mathrm{HEI}$ and transfer the role of a controller to a special IEM interest group such as the "Austrian Association of IEM's."

Figure 2 shows the adapted "German Controller Approach" that was used to control the "Quality of IEME education in HEls" to maintain and strengthen the positive image and high employment rate of IEM graduates.

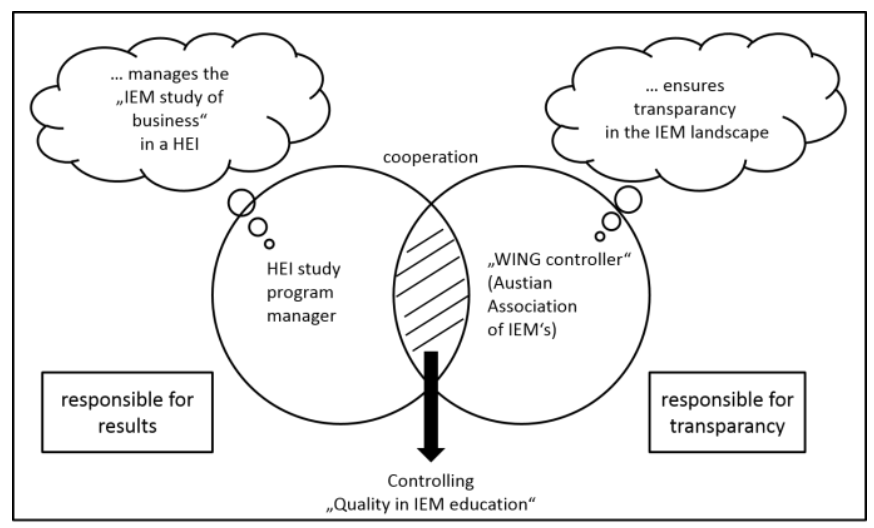

Figure 2. Adapted controlling approach to ensure high quality in IEM education $[8,14]$

HEI study program managers must manage the "education business" in institutions and are responsible for achieving the desired results. These tasks include formulating strategies and planning operations, making decisions, carrying out implementation and controlling results. A so-called "WING Controller" in the form of the Austrian Association of IEMs is responsible for maintaining transparency and providing relevant information. Their main tasks are to ensure the accuracy of and deliver advice where requested. The most important advice concerns:

- the landscape of IEM study programs in Austria,

- the competences and qualification profiles of IEMgraduates that are being sought and

- the employment rate and careers of IEM graduates.

This information must be communicated to the relevant target groups and is important to both $\mathrm{HEI}$ study program managers and HR managers in companies, IEM graduates and prospective students. These individuals, as well as politicians and other members of society, are stakeholders in the field of IEM Education programs and the IEM profession. This raises the 
question: What the term "IEM" (Industrial Engineering and Management) really means? The field of "TechnoEconomics," the interdisciplinary study and the teaching program are positioned with in a general reference frame at the interface of "technology" and "economics" [9].

The re fore, a focus of IEM study programs is placed on providing IEM students with comprehensive knowledge about engineering, economics and management. For this reason, the IEM graduates require distinctive profiles, which means a certain relation between technologies and economic subjects. The Austrian, German and Swiss Associations of IEMs have formulated a common declaration and a job specification for IEM graduates in order to harmonize the IEM qualifications across borders.

"IEM graduates are economically educated engineers with academic degrees that holistically connect their technical and economic competencies in their professional activities".[10]In order to fulfill these specifications, an analysis framework known as "the three pillars of IEM in Austria" model was created. This framework was also constructed in light of the current knowledge of the IEM field and predictions of how this field might develop. Industrial leaders expect that IEM graduates will need to have competencies in practically relevant topics as well as in diverse academic fields [e.g., 13, 14, 15, 16, 19].As shown in Figure 3, the "three pillars of IEM" have three main categories: "Natural Science and Engineering", "Integration" and "Economic Subjects".

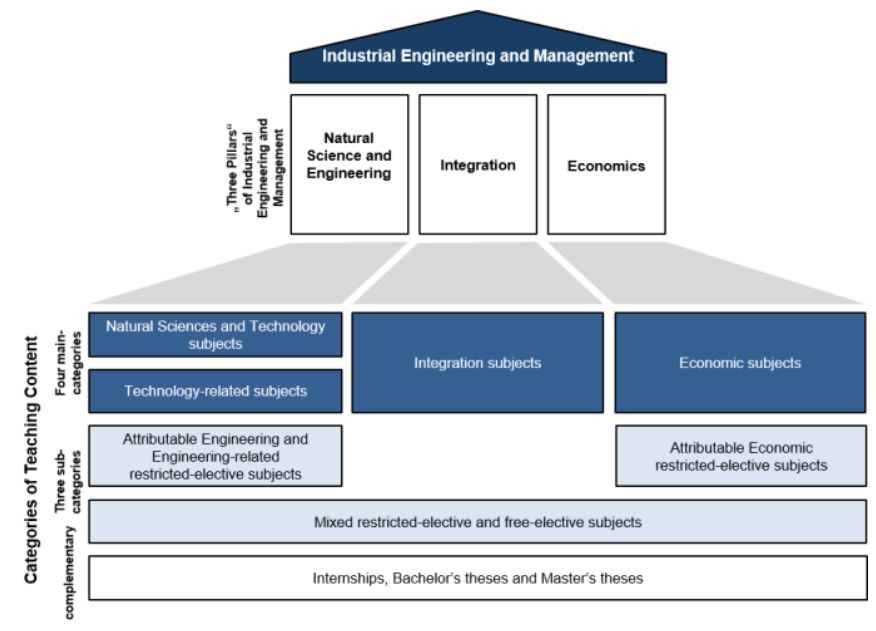

Figure 3. The three pillars of IEM in Austria [11]

\section{METHODOLOGICAL APPROACH}

To address the research questions stated in Section 1, a two-step-approach was used:

Firstly, a secondary data analysis of all IEM degree programs offered at Austrian HEls was conducted in order to give an overview of the IEM educational landscape.

Secondly, two online surveys were carried out to specify the competence profiles and determine the employment rates of IEM graduates. The target groups were initially IEM students and IEM alumni and secondly IEM and HR managers of Austrian companies.

A descriptive data analysis was conducted based on the survey responses. These results were communicated to members of the relevant target groups, and primarily to HEl study program managers, IEM students and alumni and HR managers. This study builds upon the results of previous studies that were conducted in 2010 and 2015 [17]. The study will be periodically repeated in the future.

Figure 4 shows the four-level research approach taken and gives a brief insight in to the feedback received from the study participants [18].

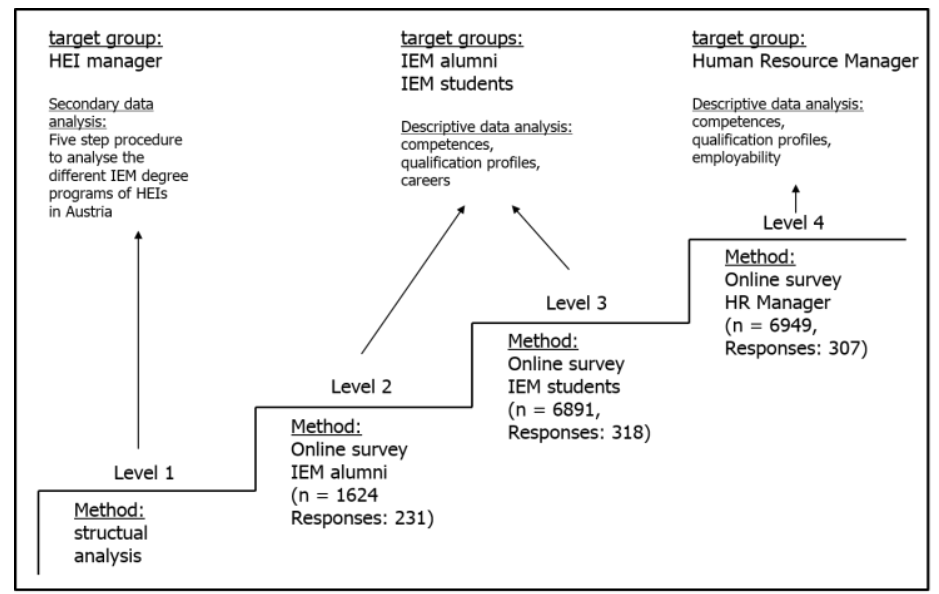

Figure 4. Four-level-research approach taken during the IEM Profession Outline Study 2018 [18]

\section{RESULTS}

This section gives an overview of the main results obtained from the study described in section 3. First, information about the IEM degree programs in Austria that were offered at universities and universities of applied science was collected. Afterwards, the ideal ratio between technical and economic subjects was determined according to the opinions of IEM graduates, IEM students and HR managers.

The outcomes of the survey regarding the desired competences of IEM professionals are explained below. In the following section, we describe the career paths and opportunities of IEM professionals are shown.

\subsection{IEM degree programs in Austria}

Our analysis of the study subjects' responses and the curricula from the universities and the universities of applied science revealed that 25 combined IEM degree programs (bachelor's and master's programs) and two IEM bachelor's programs were offered. The subjects were grouped into the categories of natural science and technology, technology-related subjects and economic and integration subjects according to the WING model (Figure 5). The degree programs offered at Austrian universities differed significantly, with a minimum of $59.85 \%$ of technical subjects offered at the University of Leoben and a maximum of $79.74 \%$ of technical subjects at the Johannes Kepler University Linz. 

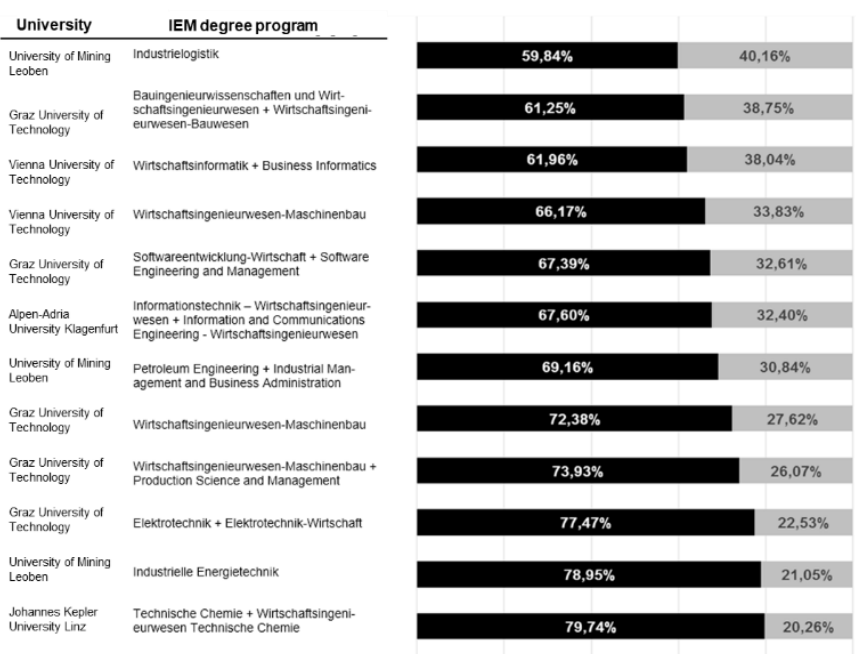

- $\%$ Tech. $\quad=\%$ Economics \& Integration

Figure 5. IEM degree programs offered at Austrian Universities in 2018 (name of IEM degree program in German) [18]

Figure 6 gives an overview of the universities of applied science in Austria that offered an IEM degree program in 2018. In total, fifteen IEM degree programs were identified that met the requirements.

At Austrian universities of applied sciences, the minimum percentage of technical subjects offered was $52.98 \%$ at the Vorarlberg University of Applied Sciences and the maximum was $76.83 \%$ at the Carinthia University of Applied Sciences.

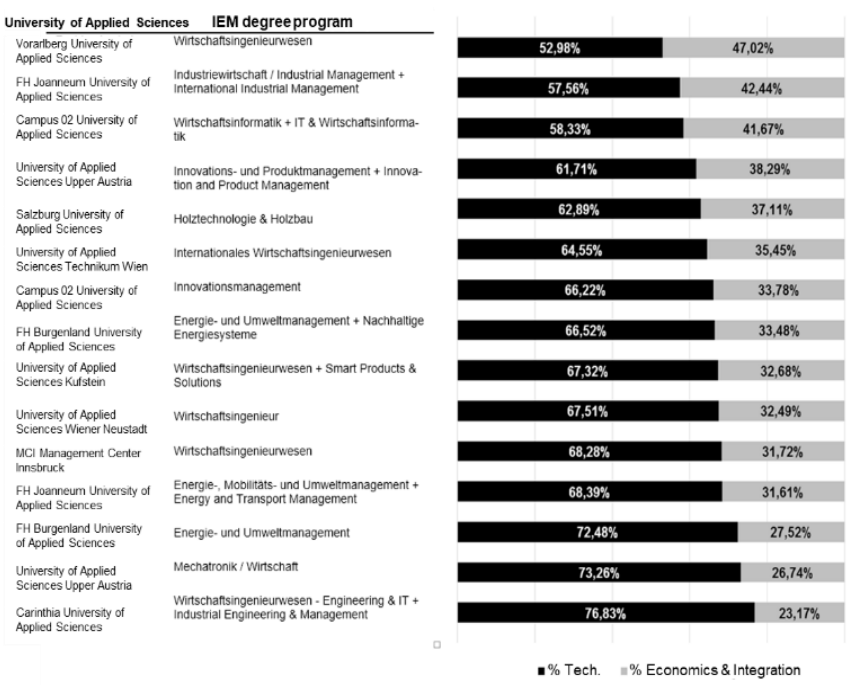

Figure 6. IEM degree programs offered at universities of applied sciences in Austria in 2018(name of IEM degree program in German) [18]

\subsection{Ratio between technical and economic subjects}

The IEM graduates answered the question of the ideal ratio between technical and economic subjects in an IEM degree program with $59.9 \%$ technical and $40.1 \%$ economic subjects and the IEM students provided the answer of $65 \%$ technical and $35 \%$ economic subjects. The HR managers stated that the ideal ratio was $59.3 \%$ technical subjects and $40.7 \%$ economic subjects, as can be seen in Figure 7.
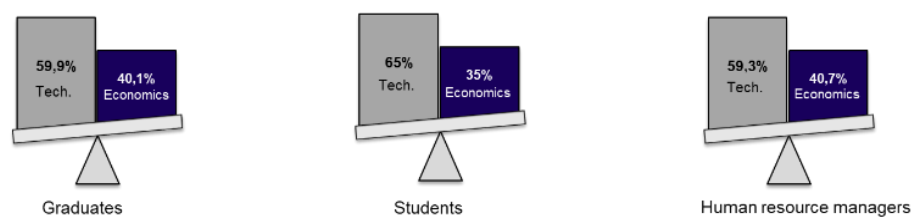

Figure 7. Ideal ratio between technical and economic subjects in an IEM degree program according to HR managers [18]

\subsection{Competences of IEM professionals}

One goal of the study was to identify the competences that industrial representatives desired IEM professionals to have.

Therefore, the ideal ratio of individual competences was first described. Then, the importance assigned to the subjects, in terms of what the study participants thought IEM graduates should know, was analyzed.

Finally, the importance assigned to the individual competences was analyzed. The question of the ideal ratio between social and methodological competencies and expertise was also addressed, as can be seen in Figure 8.

The IEM graduates believed that the ideal distribution should be $35.2 \%$ social competences, $31.1 \%$ expertise and $33.7 \%$ methodological competences.

The HR managers had similar views, considering the ideal distribution to be $34.1 \%$ social competences, $33.8 \%$ expertise and $32.1 \%$ methodological competences for IEM professionals.
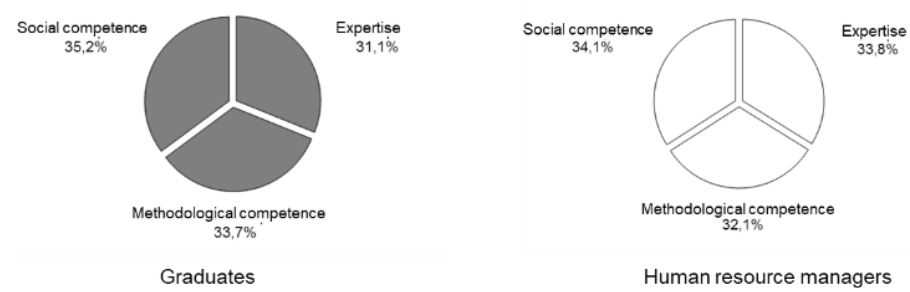

Figure 8. Ideal distribution of social and methodological competencies and expertise [18]

In Figure 9, the importance of the subject areas with regard to the competences of IEM professionals is presented.

IEM graduates as well as the HR managers considered project management to be the most important subject followed by the subjects of general business economics and general management. All listed subjects were ranked between neutral and important. 


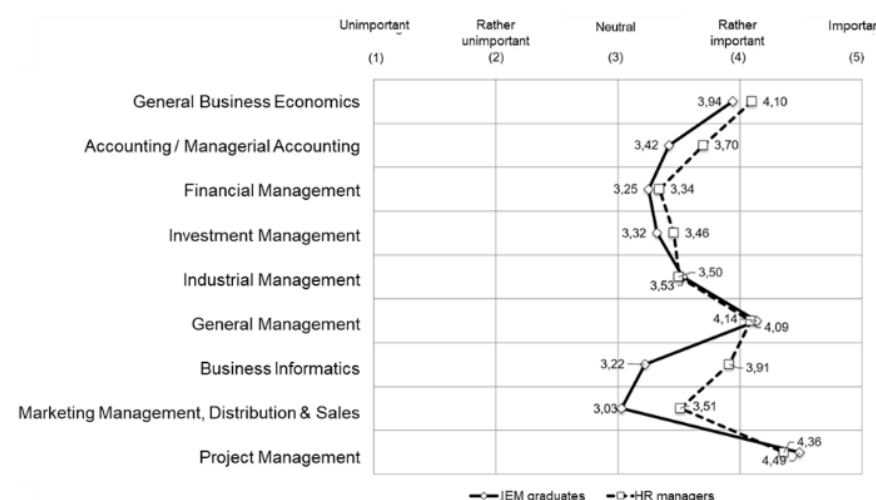

Figure 9. Importance of technic-economic subjects [18]

The importance assigned to the individual competencies from the view of the IEM graduates and $\mathrm{HR}$ managers is shown in Figure 10. Members of both target groups believed the most important one to be the "independent working" competency and ranked the "ecological and sustainable thinking" competency as neutral. All other competencies which were tested were ranked as "rather important" by the study participants.

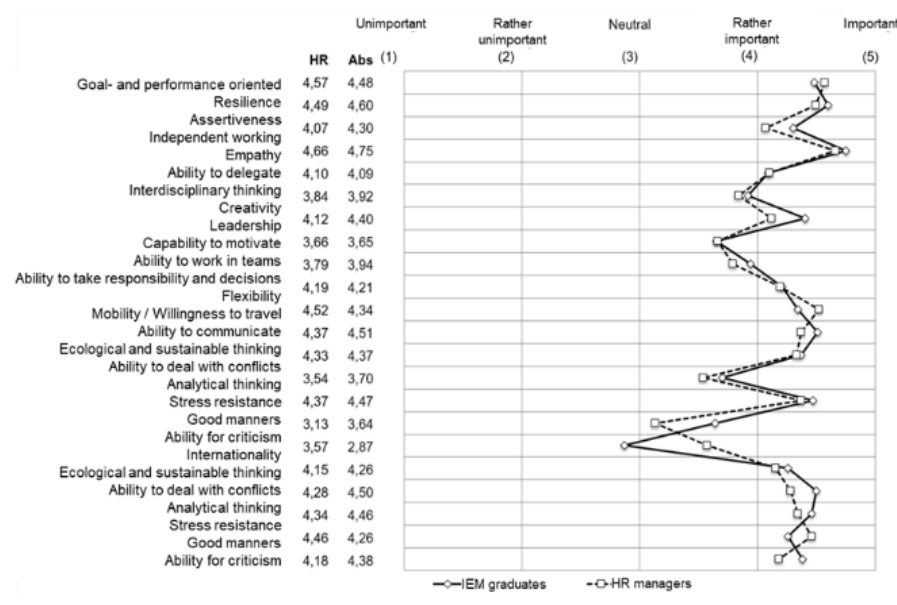

Figure 10. Importance assigned to individual competencies [18]

The IEM professionals were asked to describe their career paths from their first to their fourth job and the field(s) of operation. Results are shown in Figure 11.

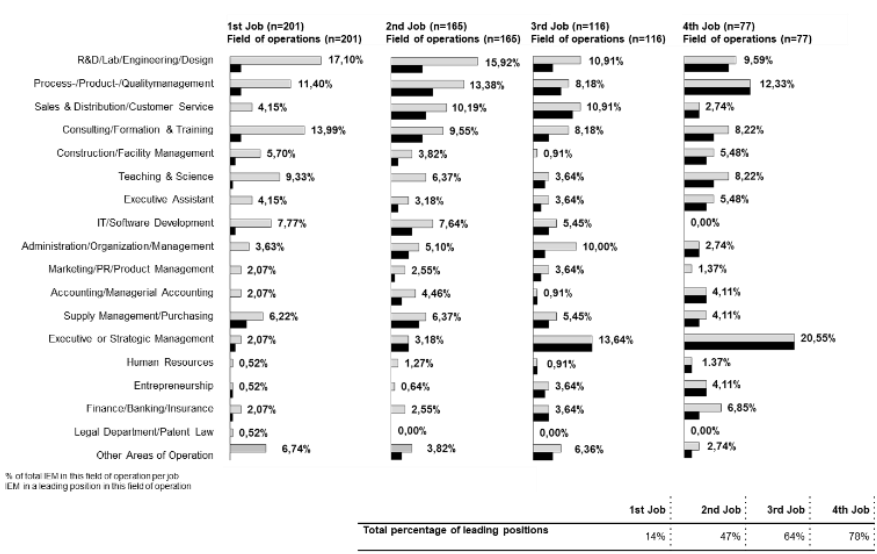

Figure 11. Fields of operation per workplace and percentage of leading positions [18]
In their first jobs, $17.10 \%$ of the participants worked in the R\&D/Lab/Engineering/Design sector. Their career paths subsequently led them to positions in the Sales, Consulting, IT, Supply and Strategic Management sectors. The total percentage of IEM professionals in leading positions increased from $14 \%$ in their first job to $78 \%$ by their fourth job.

One question that was asking during the survey was about the career and promotion opportunities of the IEM graduates. Over $80 \%$ of each of the groups (graduates/professionals, students and HR managers) answered that their opportunities were good or even very good (Figure 12).

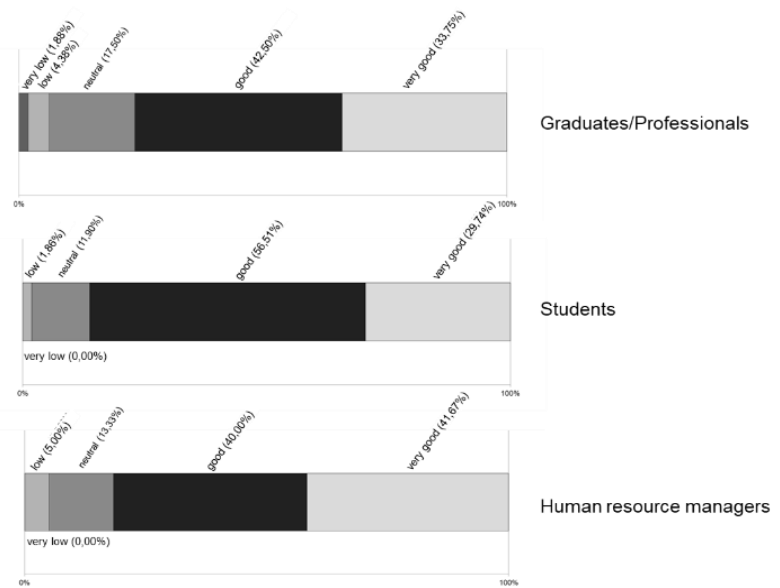

Figure 12. Career and promotion opportunities for IEM graduates [18]

\section{CONCLUSIONS}

The IEM degree programs in Austria are developing constantly. HEls modify the study programs regularly to react to possible changes in the different requirements for graduates in terms of the demands of the job market or the effects of digitalization and modernization. To ensure the quality of the IEM degree programs in Austria, these programs were examined and only the study programs which met the requirements were chosen for inclusion in this study. Consequently, the high quality of IEM education offered at universities and universities of applied sciences in Austria can be controlled.

The results of the survey show that IEM professionals are in high demand and have good to very good career and promotion opportunities. It is expected that IEM graduates will reach leading positions during their career. Of course, their career does not assure the quality of education unless these graduates go on to share their knowledge with students at HEls.

\section{REFERENCES}

[1] Baumgarten, H., Hildebrand, W.,Hirschhausen, C., Schmager, B. (2015), "Wirtschaftsingenieurwesen in Ausbildung und Praxis"Industrial Engineering and Management in Training and Practice], Verband Deutscher Wirtschaftsingenieure e.V., 14. Auflage, Berlin (in German).

[2] Veit, W. (2014), "Auf den Spuren der Technö-Ökonomie an der TU Graz im Wandel der Zeit" [On the Trail of Techno-Economics at Graz University of Technology in the Course of Time], in: 
Nachhaltige Entwicklungen an der TU Graz und ihre Indikatoren, pp. 158-168, TU Graz (in German).

[3] European Higher Education Area (1999), "The Bologna Declaration of June 1999",http://www.ehea.info/media.ehea.info/ file/Ministerial_conferences/02/8/1999_Bologna_Declaration_En glish 553028.pdf (December 17th, 2018).

[4] European Higher Education Area, 2014,Error! Hyperlink reference not valid. (December 17th, 2018).

[5] European Higher Education Area (2005), "The framework of qualifications for Higher Education Area",http://www.ehea.info/ media.ehea.info/file/WG_Frameworks_qualification/85/2/Framew ork_qualificationsforEHEA-May2005_587852.pdf

[6] European Commission (2014), https://ec.europa.eu/education/ resources-and-tools/european-credit-transfer-and-accumulationsystem-ects_en (December 17th, 2018).

[7] www.icv-controlling.com/en/association/controllers-missionstatement.html (November 19,2018).

[8] Blazek, A.,Deyhle, A.,Eiselmayer, K. (2005),"Controlling and the Controller", Controller Akademie, Gauting (in German).

[9] Zunk, B.M. (2018), "Positioning 'Techno-Economics' as an interdisciplinary reference frame for research and teaching at the interface of applied natural sciences and applied social sciences: An approach based on Austrian IEM study programmes", International Journal of Industrial Engineering and Management, Vol. 9 (1), pp. 17-23.

[10] Zunk, B.M., Sadei, C. (2015), "Sharpening the Industrial Engineering and Management qualification profile: Research findings from Austria“, International Journal of Industrial Engineering and Management, Vol. 6 (3), pp. 109-120.

[11] Bauer, U., Sadei, C., Soos, J., Zunk, B.M. (2014), "Industrial engineering and management in Austria: Comparison of qualification profiles provided by higher education institutions and career paths of graduates", Proceedings of the IIE Annual Conference and Expo 2014, pp. 1658-1667.

[12] Zunk, B.M. (2013), "Ideal-typical competence profile of industrial buyer-seller relationship controllers in technology firms. empirical evidence from Austria", International Journal of Industrial Engineering and Management, Vol. 4 (2), pp. 87-94.

[13] Zunk, B.M. (2015), "Exploration of factors influencing the customers' motivation in buyer-supplier relationships on industrial markets", International Journal of Engineering Business Management, Vol. 7, pp. 1-6.

[14] Zunk, B.M., Koch, V. (2014), "Customer ranking model for project businesses: A case study from the automotive industry", International Journal of Engineering Business Management, Vol. 6 (1), pp. 1-9.

[15] Zunk, B.M., Soos, J., Uitz, I., Denger, A., Bader, M. (2013), "The influence of human motivation factors on the successful implementation of product life cycle management tools: Explorative findings and managerial implications", Manufacturing Technology, Vol. 13 (4), pp. 580-586.

[16] Zunk, B.M., Schiele, H. (2011), "Stabilityofpricesthrough "preferredcustomerstatus"

Factorsinfluencinginnovationandpricingbehaviourofsuppliers" [Preisstabilität durch 'preferredcustomer-status': Einflussfaktoren auf Innovationsleistung und Preisgestaltung von Lieferanten], ZWF - Zeitschrift für Wirtschaftlichen Fabrikbetrieb, Vol. 106 (12), pp. 974-978.

[17] Bauer, U., Sadei, C., Soos, J., Zunk, B.M. (2014), "Ausbildungslandschaft, Kompetenzprofil und Karriereweg von WirtschaftsingenieurInnen - Studie 2014" [Education Landscape, Competence Profile and Career Path of IEMs Study 2014], Institute of Business Economics and Industrial Sociology, Graz University of Technology, Graz (in German).

[18] Bauer, U.,Priebernig, S., Swobodnik, S., Zunk, B.M. (2018), "Wirtschaftsingenieurwesen - Berufsbildstudie 2018" [Industrial Engineering and Management - Outline of a Profession 2018], Institute of Business Economics and Industrial Sociology, Graz University of Technology, Graz (in German).

[19] Bauer, U., Theuretzbacher-Fritz, H. (2015),"How to control university subsidiaries: The management approach of Graz University of Technology", International Journal of Industrial Engineering and Management, Vol. 6 (4), pp. 143-151.

\title{
Kontrola kvaliteta industrijskog inženjerstva i menadžmenta: Strukturna analiza austrijskih studija i implikacije za institucije visokog obrazovanja
}

\author{
Ulrich Bauer, Sigrid Weller
}

Primljen (28.12.2018.); Recenziran (22.01.2019.); Prihvaćen (13.02.2019.)

\begin{abstract}
Abstrakt
Programi industrijskog inženjerstva i menadžmenta (IIM) su uvek bili popularni i uspešni, posebno u poslednjih trideset godina. Mnoge institucije visokog obrazovanja (VO) nude širok spektar studijskih programa, a taj raspon se $i$ dalje širi. To je dovelo do problema da različiti programi i kvalifikacioni profili više nisu jasno uporedivi. Austrijsko udruženje IIM-ova (VING) tražilo je rešenje koje bi osiguralo visok kvalitet IIM studijskih programa i mogućnost zapošljavanja IIM stručnjaka. Stoga je odabran kontrolni pristup koji je doveo do zadovoljavajućih rezultata, pre svega u pogledu transparentnosti. $U$ ovom radu prikazan je pristup i rezultati strukturne analize $i$ dva online istraživanja koja su sprovedena u okviru IIM profesionalne online studije sprovedene 2018. godine.
\end{abstract}

Ključne reči: Industrijsko inženjerstvo i menadžment, studijski program, kontroling, visokoškolska ustanova, profil kvalifikacije, zapošljivost, kvalitet 